\title{
ISLAMIC EDUCATION AND ISLAMIC REVIVALISM IN INDONESIA: A CASE STUDY OF KUTTAB AL-FATIH PURWOKERTO
}

\author{
Aji Sofanudin ${ }^{1}$, Ahwan Fanani ${ }^{2}$, and Rahmawati Prihastuty ${ }^{3}$ \\ 1 Office of Religious Research and \\ Development, Ministry of Religious \\ Affairs Semarang, Indonesia \\ ajisofan@gmail.com \\ ${ }^{2}$ Faculty of Social and Political Sciences \\ UIN Walisongo Semarang, Indonesia \\ ahwan.fanani@walisongo.ac.id \\ ${ }^{3}$ Department of Psychology, \\ Faculty of Education, \\ Universitas Negeri Semarang, \\ Indonesia \\ rahmawati.prihastuty@mail.unnes.ac.id

\begin{abstract}
Kuttab is a new phenomenon in the Indonesian education system. Apart from pesantren, madrasa, and Islamic schools which are publicly familiar and formally recognized by the Indonesian government, kuttab new actor and joins the Islamic education arena with the specific offer on Quranic and Islamic belief learning. This study aims at revealing ideological roots of Kuttab Al-Fatih (KAF) and analyzing its educational concept. Kuttab Al-Fatih is selected because of its rapid spread and success to establish 34 branches throughout Indonesia. Using a qualitative approach to study KAFs in Purwokerto, the study shows that KAF embraces conservative and fundamentalistic thought in Islam. The educational concept of kuttab is idealizing past glorious Islamic institutions and civilization. Therefore, the spirit of KAF is to restore ideal Islamic education of the past.
\end{abstract}

Paper received: 27 February 2021

Paper revised: 14-21 June 2021

Paper approved: 14 July 2021
Keywords: Conservative, fundamentalistic, Islamic education, Kuttab Al-Fatih, revivalism

\section{INTRODUCTION}

The emergence of kuttab adds the actors of educational activities in Indonesia with new educational institution types and systems outside those that have been previously and commonly recognized by the Indonesian government. In Indonesia, there are three educational institutions widely known namely pesantren, madrasa, and schools. The dynamic and growth of pesantren, madrasa, and schools have been discussed comprehensively by Kareel Steenbrink (Steenbrink 1986: 1-102) and all of those types of educational institutions are still growing and developing (Haningsih 2008). It is also important to note here that the manifestation of the development of pesantren, madrasa, and schools takes traditional model of the institution, modern model, the mixture between traditional and modern institution, and alternative models, such as nature-based Islamic education (Sofanudin 2019a). While kuttab comes up with a new system of education stemming from the past model of basic Islamic educations in early Islam (Sofanudin 2019c).

The kuttab, however, faces a challengein which it is not integrated into Indonesian education system yet. It is not integrated in the regulation of the Ministry of Religious Affairs (MORA) or Ministry of Education, Culture, Research, and Technology. Currently, Islamic educational institutions in Indonesia can be categorized into formal and non-formal educations as well as into state and private owned institutions. Formal educational institution comprise madrasas, from basic education to higher education that managed by the Ministry of Religious Affairs (MORA). While Islamic schools, from basic education to senior high schools, managed by the Ministry of Education. The non-formal educational 
institutions comprise of pesantren, either traditional, (salafiyyah) or modern (khalafiyah) and also Taman Pendidikan al-Quran (TPQ) held in mosques. Nevertheless, kuttab does not attach to the Indonesian education system yet, while it requires formal recognition by the government to allow its students in pursuing subsequent formal educations.

The Government try to standardize the curriculum of formal Islamic education, while the curriculum of non-formal is let open to be formulated by each institutions. For formal educations (madrasa) under MORA, Islamic teachings are given more emphasize and divided into several subjects, such as Fiqh, Islamic history, Arabic and the Quran and Hadith (prophetic tradition). In Islamic school under the Ministry of Education, all those subjects compressed into one, namely Islamic religious education (Pendidikan Agama Islam). Therefore, it is safe to say that more time is allocated for Islamic teachings in madrasa than in schools (Wardi, Ismail, and Makki 2019: 30-32).

The standardization of the content of Islamic Education informal education does not prevent the management or the owners of madrasas and Islamic schools to include local contents which suitable for the local demand or for sake of the dissemination of specific ideology embraced by Islamic mass organization. Schools and madrasas that managed by Muhammadiyah have a specific subject called "al-Islam dan Kemuhammadiyahan" (Islam and Muhammadiyah) for nurturing Muhammadiyah's Islamic character and ideology (Baidarus, Tasman Hamami, and Fitriah M. Suud 2019). This goes similar with educational institutions managed by the Nahdlatul Ulama which provide Ahlussunah wal Jamaah (Aswaja) content that highlights the ideology and the attitude of Nahdlatul Ulama (Fahmi 2016). In the 1990s integrated Islamic schools under the Tarbiyah or Revivalist movement emerged. In its journey, each integrated Islamic school (SIT) has various typologies (Sofanudin 2019b). Currently, scholar connects this development with kuttab that has various names (Sofanudin, et al. 2021).
The development of kuttab changes the maps of Indonesian Islamic education. It then raises the interest of researchers to reveal this phenomenon. The most recognized kuttab in Indonesia is Kuttab al-Fatih. Riyadi (2019) regards the kuttab phenomenon as the proof that Islamic community in Indonesia have faith in the concept of prophetic model of education. Nelliraharti, et al. find out that Kuttab al-Fatih tries to involve parents so they pay more attention to their children education through parenting program as happens in Kuttab al-Fatih Banda Aceh (Nelliraharti and Sari 2019). Meanwhile, Saugi highlights the implementation of Curriculum in Kuttab al-Fatih for Children Education at an Early Age. He notes that Kuttab al-Fatih implements thematic learning of Curriculum 2013 which is supported by children's parents (Saugi 2020). Ulwiyah, et all confirm the process of character internalization in Kuttab AlFatih Jombang through habituation (Ulwiyah, Maftuhatin, \& Samsukadi 2019). The previous articles show that kuttab education gets more attention from academics.

However, the Ministry of Education and Culture as well as the Ministry of Religious Affairs do not have database on the number of kuttab in Indonesia yet because formally $k u t t a b$ are not registered as other educational institutions to the Ministry of Education or to the Ministry of Religious Affairs. The kuttab also-some of which-do not have operational permit yet. Therefore, according to finding of Sofanudin's study, kuttab can be classified into four categories: those that have an operational permit as a Community Learning Activity Center (PKBM) under the Education Office; those as equality education for basic level (ula) under the Ministry of Religious Affairs; those as the one that has another PKBM; and the rest do not have an operational permit yet (Sofanudin 2019c).

In some areas, kuttab have developed and begun to root in society. Some kuttabs established in Central Java, such as Kuttab alFatih (KAF) Purwokerto, KAF Tegal, Kuttab Ibnu Abbas Surakarta, Kuttab Harun Al-Rasyid Surakarta, Kuttab Ibnu Abas Klaten, Kuttab Al- 
Jazary Surakarta, and Kuttab Al-Ayyubi Kendal (Sofanudin 2019c). Kuttab Al-Fatih has the most branches, as many as 33 branches. In Central Java, at least there are three KAF branches that have been established namely KAF Semarang, KAF Purwokerto, and KAF Tegal. Despite of the operational permit issue, kuttab survives and attracts their clients widely.

There are many reasons why kuttab is attractive. The important aspect is ideological one. The growth of kuttab attracts academic persons and researchers to conduct research and studies on them. One of them is Hidayat (2018) who study of ideological aspect kuttab, but he focuses on the ideology of education underlying kuttab. He emphasizes on factual analysis rather than textual one so that he ignores original sources written or compiled by the founder of the kuttab. Hidayat, however, pay less attention on the relationship between kuttab and ideological aspect driving the revitalization of them (Hidayat 2018). Kuttab is a traditional Islamic educational institution revived recently through the projection of the glorious past of Islam.

In fact, the emergence of contemporary $k u t t a b$ cannot be deprived from their socioreligious background. The revitalization of Islamic institution is common aspiration of Islamic revivalism wave that has entered Indonesia since 1970s. The Islamic revivalism brought with it the enthusiasm for reviving glorious past of Islam as model to revive Islamic values in modern society. The movement started in general campus and spread in wider society to implement and to manifest the true path of Islam in Indonesian society (Bisri 2002). The movement started in general campus and spread in wider society to implement and to manifest the true path of Islam in Indonesian society (Fuaduddin 2002: 250). Education, according to Yumitro, provides an opportunity for Islamic revivalism to spread and influence Islamic society in Indonesia, along with historical background of Islam in Indonesian and the Islamization wave in public policy (Yumitro 2018).
Fazlur Rahman puts revivalism of neo revivalism an antithesis of the wave of modernization in Islamic world driven by the West's influences. From educational perspective, Rahman finds out that religious revivalism in higher Islamic Education was a response to classical Islamic modernism that adopt Western system and educational thought without critical attitude. Rahman, however, criticized the revivalism as having weakness in the developing intellectuality (Rahman 2013)

For the preceding reasons, this article is aimed to deepen the understanding on the ideology of kuttab, as has been explored previously by Hidayat (2018), and to reveal the concept of Islamic education of kuttab, that fail to be taken seriously by the previous studies. This study took a research object of Kuttab Al-Fatih (KAF) Purwokerto. This article will answer three questions on the intellectual and ideological background of the founders of the KAF; on the ideology of education embraced by KAF Purwokerto, and on the implications of KAFs concept of Islamic education. This article is based on qualitative research and employs descriptive analyses approach for studying the KAF Purwokerto.

\section{LITERATURE REVIEW}

Islamic education institution has developed from the early of Islamic history. Makdisi noted several institutions started in mosques, such as majlis or jalsah, halaqah, zawiyah, and madrasa. Such institution of learning subsequently not only developed in mosques but also in the houses of teacher who opened private or public Islamic teaching as well (Gulliot 2012: xxix). Maktab and kuttab were an elementary institution of Islamic learning to prepare student before continued their study to halaqah in Jami mosques or to madrasa. Kuttab and maktab provide basic education on al-Quran and writing of Arabic letter (Makdisi 1981: 19).

Along the history, Muslim scholars formulate several terms representing the notions of Islamic 
education. There are eight terms which have been known in Islamic education, namely al-tarbiyah al-diniyah (religious education), ta'lim al-din (religious teaching), al-ta'lim al-diny (religious teaching), al-ta'lim al-islamy (Islamic teaching), tarbiyah al-muslimin (education of Muslims), al-ta'lim al-islamy (education in Islam), altarbiyah inda al-muslimin (Islamic education among Muslims), and al-tarbiyah al-islamiyah (Islamic Education) (Muhaimin, Sutiah 2012: 36). Some terms are used interchangeably to refer the practice of Islamic teaching in Islamic world. Some other, however, have slightly different connotation and represent specific tenets that differ from other terms. Tarbiyah and ta'lim, for instance, have different tone in which the former refers to the development of human capacity and the latter refers to cognitive aspect of educational process.

Naquib Hossein al-Attas, contemporary Muslim scholar, differentiate clearly the terms of tarbiyah, ta'lim, or ta'dib. He put ta'dib as ideal and comprehensive concept of Islamic education consisting of tarbiyah and ta'lim. Tarbiyah, as he suggests, focus on the physical and mental development, while ta'lim put more emphasize on cognitive or intellectual one. He proposed the combination between tarbiyah and ta'lim in ta'dib by integrating knowledge, morality, and spirituality. Ta'dib is the core notion of Islamization of knowledge (Al-Attas 1980).

In the Indonesian context, ta'dib is represented by the term of tarbiyah so that the faculty of education in Indonesian higher education is named Tarbiyah Faculty. The Tarbiyah Faculty holds Islamic education (altarbiyah al-diniyah) which provide student with al-ta'lim al-dini (religious teaching) and ta'lim al-islami (Islamic teaching), along with the workshop of the teaching skills and the design of teaching-learning. In Indonesia, Islamic education under The Ministry of Religious Affairs teach both Islamic and secular subjects, but with the more proportion for Islamic traditional knowledge, such as Fiqh, Akhlak, Hadith, and Islamic history (Wardi, Ismail, and Makki 2019:
30-32). Conversly, general education under the Ministry of Education provides general education with very less religious subjects. Nowadays, the interest to integrate Islamic and secular knowledges lead to the inclusion of more Islamic subject into Islamic schools under the Ministry of Education (SDI, SMPI, and SMAI) and of more secular subjects into Islamic schools under the Ministry of Religious Affairs (MI, MTs, MA, and $U I N$ ) from the level of elementary education institutions to the higher learning institutions.

Islamic educational institutions in Indonesia can be categorized into formal and nonformal educations as well as into state and private owned institutions. Formal educational institution comprise madrasas (RA, MI, MTs, MA) that belong to The Ministry of Religious Affairs and Islamic schools (SDI, SMPI, and SMAI) that belong to The Ministry of Education. The non-formal ones comprise pesantren, either traditional (salafiyah), modern (khalafiyah) or combination of both under MORA and also Taman Pendidikan al-Quran (TPQ) held in mosques. Several Islamic educational institutions are owned and run by government and the rest are owned and run by Islamic mass Organization in Indonesia, such as Muhammadiyah, Nahdlatul Ulama (NU), Al-Irsyad, Mathlaul Anwar, Persis and Nahdlatul Wathan.

The standardization of the content of Islamic education informal education does not prevent the management or the owners of madrasas and Islamic schools to include local contents suitable for the needs of local society or for sake of the dissemination of specific ideology embraced by Islamic mass organization. Schools and madrasas under Muhammadiyah get al-Islam (Muhammadiyah's Islam) and under Nahdlatul Ulama get Ahlussunah wal Jamaah (Aswaja), both of which give information on the history, leaders, and religious thought embraced by Muhammadiyah and NU. In 1990s there have grown integrated Islamic schools under Tarbiyah or Revivalist movement. In its journey, each integrated Islamic school (SIT) has various typologies (Sofanudin 2019b). Studies of Islamic 
Education in Indonesia have multiplied due to kuttabs. Ideology, therefore, play an important role in shaping Islamic education orientation in Indonesia, especially in private owned schools and madrasas.

Ideology is a construction of understanding. Ideology, according to Eagleton (1991: 1-2) is a set of belief motivated by social interest. Ideology is said to be a system of ideas about phenomena, especially phenomena of social life. Ideology is a unique way of thinking by a group or individual. In the context of Islamic education, the perspective of a phenomenon is sometimes influenced by a broader typology of religious thought (Hidayat 2018: 88). Ideas about phenomena can be related to political, economic, educational, social or cultural systems. The ideology of education in Indonesia must be in harmony with the four pillars, namely Pancasila as the basis of the state, the 1945 Constitution as the state constitution, the Republic of Indonesia as the form of the state, and Bhineka Tunggal Ika (the Unity in Diversity) as the motto of the state.

The Act Number 20/2003 on the National Education System, Article 2, states that national education is based on Pancasila and the 1945 Constitution. Article 3 states that National education functions to develop capabilities and shape the dignified character and civilization of the nation in the context of educating the life of the nation and aims to develop the potential of students to become human beings who have faith and are devoted to God Almighty, noble, healthy, knowledgeable, capable, creative, independent, and become citizens who are democratic and responsible.

William F. O’neil divides educational ideology into two, which are (a) conservative ideology, which includes several streams: fundamentalism, intellectual education, and educational conservatism (b) liberal ideology, which is divided into sub-ideologies: educational liberalism, educational anarchism, and educational liberationism (Hidayat 2018). According to Muhaimin, the paradigm of Islamic education consists of (1) the paradigm of formism, in which aspects of life are viewed dichotomically and discrete. The development of Islamic education is more oriented to the afterlife. Students are directed to be loyal have a high commitment and dedication to the religion being studied. Studies that are empirical, rational, analytical-critical, are considered to be able to shake the faith so that a normative and doctrinal religious approach needs to be suppressed, (2) a paradigm of mechanisms, in which viewing life consists of several aspects, and education is seen as planting and developing a set of life values. Religious education is more prominent moral and spiritual or affective functions than cognitive and psychomotor in the sense that cognitive and psychomotor dimensions are directed to affective (moral and spiritual) development that is different from other subjects (3) the paradigm of organisms in which Islamic education is a unit or as a system (consisting of complicated components) which seeks to develop a view/spirit of life (weltanschauung) of Islam, which is manifested in Islamic attitudes and life skills (Muhaimin, Sutiah 2012: 39-47).

One concept that can be considered related to ideology is the one of the relations of religion and the state. The relation between the state and religion is at least divided into three patterns. The first is a state based on religion. In this model, there is a union of state and religious authority holders (waliyul amri kalifatullah sayyidin panatagama, Caesar opapisme). The state and state authority holders are run based on certain religions. In this state model there are two possibilities, where citizens are required to embrace the official religion of the state and other possibilities citizens are given the freedom to embrace religion according to their beliefs. Second, religion is as a state spirit. In this model the state does not formally adhere to a particular religion, but religious values are the spirit of organizing and administering the state, and there is a guarantee from the state for citizens to embrace a particular religion and worship based on their religious beliefs. The third is the secular state. In this model state there is a separation of 
state authority and religion, or in an extreme the state does not take care of religion, and so does religion not related to the state. Indonesia is more appropriately adhering to the second model; the state of Pancasila gives ample scope to religion. Religion becomes a state spirit (Asy'ari 2011).

Indonesia is neither a country based on a particular religion (theocracy) nor a country that separates religious and secular affairs. Although Indonesia is not a religious country, it is more properly called Indonesia as religious country. A country ensures that every citizen is free to embrace a religion and worship according to his or her beliefs (Sofanudin 2012: 1). The founding fathers of the nation, after going through deep reflection, chose Pancasila as the value of the nation and state. Therefore, religious education is not intended to establish a state based on religion (theocracy) but rather to strengthen the state of Pancasila. Religious relations in the Indonesian context are different from those of the United States that are more secular. Indonesia is also different from Saudi Arabia and the Vatican that tend to ad-Din wadaulauh, in which religion is country and country is religion. Religion becomes the spirit of state maintenance; religion is the inspiration for the advancement of the nation.

Education is area in which ideology, either religion or nation, is implanted and reinforced. Islam (religion) and nationalism is two fold aspect that shape Indonesian Ideology and, consequently, influence the ideology of Islamic education. Education now serves as enculturation mechanism for religious outlook as well as for national interest. The dynamic of Islam and nationalism sparks heat debate and discussion in recent political arena and also draws education as part of the institutionalism of specific religious or national tenets. Kuttab is not excluded from the actual discourse the role of education as an instrument for ideological dissemination.

Substantially, the kuttab curriculum is more similar to an Islamic religious education institution. Kuttab is a pesantren without a dormitory (Sofanudin 2021). Although in licensing there is also a licensed kuttab under the education office (nonformal education or PKBM), not under the Ministry of Religious Affairs Indonesia (Sofanudin 2019c). Kuttab still sounds foreign to the ears of the common people. Even though kuttab is a historical tradition since ancient times in the form of a small place next to a mosque where young children learn the Quran. As an educational institution, kuttab even existed before Islam (Sofanudin, et al. 2021).

\section{RESEARCH METHOD}

Research on kuttab is an interesting topic due to the rapid growth of kuttab and due to ideological concern rising in the contemporary Indonesia. So far, the Ministry of Education and MORA do not have data base on the number of kuttab in Indonesia, but their observance get more visible in the educational spectacle. Kuttab institution is under the process of definition regarding coaching conducted by the government. Many officials in education do not aware of the existence of the kuttab as new phenomena in Islamic Indonesian education. The ideological roots of kuttab need to be revealed because there is suspicion on the commitment of kuttab to the State of Indonesia.

This research is a qualitative case study research on KAF. Qualitative inquiry, according to Creswell (2009: 178-189), encompasses the processes of data collection and data analysis. Data collection procedures includes the identification of sites or individuals for study, indicating the types of data and data recording. Data analysis is ongoing process during the research involving several steps, namely organizing and preparing data for analysis, reading data thoroughly, coding process, using coding process to generate a description, advancing description for presenting narration and making interpretation.

Primary data sources were obtained at KAF Purwokerto. Secondary data included books, website information, and documents containing KAF. Data are also collected from main source entitled "Modul Kuttab Satu; Al-Fatih Pilar 
Peradaban" written by the founder and ideologist of Indonesian KAF, Ust Budi Ashari. Other books available and used in KAF are also taken into account, such as: the natural module, the human module, and tadabbur Quran. The data are triangulated with other data obtained from the officials of the Ministry of Religious Affairs in Banyumas Regency, the Banyumas District Education Office, and people surrounding the KAFs.

The study also considers the roots of kuttab to give brief understanding of its history. Although kuttab is new phenomenon in the Indonesian Islamic education, it stems from long history of Islamic educational institution. The understanding of dynamic and development of kuttab as Islamic educational institution will enable readers to comprehend Kuttab al-Fatih in the light of long history of Islamic education. The historical background of kuttab employees historical reading that will be provided in the subsequent sub chapter.

Kuttab Al-Fatih is selected as case based because of its rapid spread and success to establish branches in Indonesia. There are 34 branches of KAF throughout Indonesia, three of which are located in Central Java. Central Java is home for three KAF, namely KAF Semarang, KAF Purwokerto, and KAF Tegal. The research focused on them in Central Java KAF, with specific reference to Kuttab Al-Fatih in Purwokerto. The focusing on Kuttab Al-Fatih Purwoketo is due to the establishment of it.

Observations were made at KAF Purwokerto. KAF Purwokerto has already had an operational permit as a PKBM from the Banyumas Regency Education Office. Sources of data included the head of the kuttab, religious teachers, students, parents, guardians, officials in the Ministry of Religious Affairs in the field of Islamic education, madrasas, and the Islamic Community Guidance, as well as officials in the education service in the field of community education dealing with the PKBM. The main books used in the kuttab were also the sources such as: kuttab module one, natural modules, human modules, tadabbur Quran, daily mutaba'a (the supervision of programs), report cards, and the results of student research on kuttab.

Data collection technique was carried out through observation at KAF Purwokerto. Document review was carried out on books, published by the Kuttab Al-Fatih Foundation, other people's studies, and studies of kuttab. The analysis technique used was the descriptive model of Miles and Huberman including: data reduction, data display, interpretation. The results of observations, interviews, and document reviews were collected and sorted according to the categories. After that, the data was selected in accordance with the research objectives of finding out ideological roots of Kuttab Al-Fatih. Interpretation was done by comparing theory with practice, between so called das sollen and das sein between the ideology of Pancasila with the ideology of the Khilafah. To read this phenomenon, the theory of relations of religion and state was used: integration, secularization. Analysis was carried out on the text (paper) published by the Al-Fatih Foundation and the context (person, place) associated with Kuttab AlFatih. Data analysis was carried out by means of a qualitative descriptive method of KAF phenomena in aspects: history, ideology and implications.

\section{RESULT AND DISCUSSION}

\section{Short History of Kuttab}

The term kuttab is derived from the word katib which means writer. Some say that kuttab or maktab is derived from the word kataba which means to write or place to write, so kataba is a place to learn to write. In another opinion, kuttab is the beginning of a place of learning in the Islamic world taken from the word taktib, which means teaching writing. In the common usage of Modern Arabic, kuttab is adjacent to the word maktab which means "office", while maktabah means "library" or "(place of study)" and kuttab is a plural word meaning of "book" (Muspiroh 
2019). Before the advent of Islam, kuttab had existed in Arab countries, although it was not widely known by the public. There are different opinion on the origin of the institution of kuttab in Islam. Some scholars see the similarity between kuttab in Islam and basic education in Byzantine. Others stated that kuttab existed before Islam and related to Jews. Zaid bin Tsabit, a companion of the Prophet, learnt from Jews schools in Yathrib before the hijrah of Muhammad (Gulliot 2012: xxix). Kuttab education is held at the teacher's house (mu'addib, Mu'allim), at the homes of the memorizers of al-Quran, in mosques or yards around the mosques. This educational institution is only a place to learn how to read and write for children (Muspiroh 2019). Kuttab developed to be elementary education for student before they continue their study to halaqah. Basically, kuttab dan maktab refers to the same object, but in Nisapur maktab is prerequisite for toddlers (under 5 years) before they attend kuttab (for 10 years old students and over). Maktab is aimed to provide students with learning of Quran and belief, while kuttab is aimed to provide them with literacy, writing, and memorizing book on one subject (Makdisi 1981: 19).

There were two types of kuttab. First, kuttab that provides teaching, reading and writing of basic Arabic texts of poetry. The teachers were commonly non-Muslims, at least in the early days of Islam. Second, kuttab that acted as the institution of teaching Quran and the basics of Islamic teachings. Many scholars, like Phillip K. Hitti, Ahmad Amin, and Ignaz Goldziher, believe that reading and writing the Quran and the basic of religious teachings have been taught in the same Kuttab since the earliest times of Islamic development (Baiza 2018: 81-82; Tafsir 2004: 261). Batubara and Ariani sum up the function of kuttab into four: kuttab as a literacy education institution; kuttab as an educational institution of Quran and Islamic religious learning; kuttab equipped with a building for teaching both religious and general sciences; and kuttab as lower education in the palace (Batubara and Ariani 2016: 103-105).
Kuttab in Islam received more popularity in the Era of Umayyid (661 - 750), spread in the era of Early Abbasid (750-1258 M), and lasted subsequently in Islamic countries before the penetration of The West into Islamic world. In Morocco, kuttab serves as elementary Islamic education before students pursue their study to madrasa and then to mosque university. Mosque university refers to advanced level of Islamic education which provide the study of higher level of Islamic works, such as Majmu' Syarah Muhadzdzab, Tafsir, theology, or philosophy. Kuttab in Morocco are located in both rural and urban area with emphasize on the memorizing of the Quran. Kuttab could be accessed by most students due to its location in villages or towns, while madrasa was only available in town or cities. Up to now, kuttab and madrasa exist in Morocco, along with the development of modern educational institutions (Boyle and Boukamhi 2018: 626-627).

\section{The Portrait of Kuttab al-Fatih}

Kuttab Al-Fatih (KAF) was founded in 2012 by Muhaimin Iqbal, Budi Ashari, and Waalid Ilham (www.kuttabalfatih.com). The establishment of KAF is driven by the fact that Islamic education face difficulties to tackle the issues of juvenile delinquents, such as brawls, drugs abuse, and free sex. KAF's founders have big concern on negative impacts of globalization toward juvenile character development. They also see challenging situations that cover the existing and development of Islamic institutions, such as pesantren, madrasa, and integrated Islamic schools. KAF would like to establish a vision to create Quranic generation. The Muslim generation is capable of world domination and capable of becoming leaders. KAF aims to educate bright generation in young age based on Islamic belief and Quranic studies.

The history of kuttab spans in the Islamic kingdoms existed in Nusantara. It says that kuttab has existed since the era of the Siak Sri Indrapura Sultanete. The kuttab is in the area of the Islamic Sultanate complex Siak Sri Indrapura 
Riau. Siak Sri Indrapura Sultante is an Islamic Malay Kingdom that was once is located in Siak Regency, Riau Province, Indonesia. This sultanate was founded in Buantan Raja Kecil from Pagaruyung with the title Sultan Abdul Jalil in 1723, having previously been involved in the struggle for the throne Johor (Sandy 2021). However, KAF Depok is the first kuttab of its kind which established in modern time of Indonesia.

Purwokerto KAF is a branch of KAF Depok, West Java. KAF Purwokerto was established by PJ Syar'i KAF Purwokerto in 2014. It is located on Kenanga 10 Street, Number 01 RT 004/RW 002 Sumampir Village, Purwokerto Utara District, Banyumas Regency, Central Java Postal Code 53125 phone 0281-623391. In Central Java, there are three Al-Fatih Kuttabs located in Semarang, Purwokerto, and Tegal. They are part of $33 \mathrm{KAF}$ institutions in Indonesia. KAF Purwokerto, in terms of licensing, is a PKBM unit with notarial deed number 205 dated May 20, 2017 with Establishment License number: 421.9/709/2017. The Kuttab was named Al-Fatih because it was inspired by Al-Fatih, a title pinned on Mehmed II, the seventh Sultan of Ottoman Turkey.

The curriculum of KAF aims to prepare the best generation of Islam as the generation of ala minhaji nubuwwah (Utomo 2018: 142). The generation withQuraniceducation. Thegeneration with leadership skill such as Muhammad AlFatih, Ottoman Ruler, who at his young age could conquer Constantinople. The Quran is the main source of study at KAF. Therefore, the curriculum of KAF consists of Quran and al-Iman (Islamic belief). This distinguishes the teacher (ustadz) in kuttab into two categories: the teachers of aliman and the teachers of Quran. At the present, class at kuttab is divided into two levels: early and qonuny kuttab. The former is aimed to teach children to read, to write, and to memorize Quran as well as basic sciences of religion and counting. The latter is for children and adolescents who take specialty in the study of linguistics and ethics, religious sciences, hadith, and various other sciences (Pratama 2016: 25).
$\mathrm{KAF}$ is an independent institution which is managed without relying on government assistance. The independence is built on basic values of the KAF. KAF is held under several basic values, namely non prejudiced; knowledge before charity; and pre-Quranic faith. Kuttab attempts to revive the success of Islamic civilization in the past. The name of kuttab itself was chosen because it was the "legacy" of the Prophet so that the spirit of the restoration of Islamic education is prevalent in the KAF world view.

The learning model developed by KAF based on tempo doeloe (classical) model, referring to model believed to be ideal model from Islamic traditions. The approaches of learning include modeling, habituation and experiential ones throughouting class. Themethodsusedaretalaqqi, memorizing tasmi', drilling, lecture, question and answer, stories, and parables. The evaluations include theme examinations and juz incremental, final exams, daily reflection, participation, daily assignments, and memorization (Putranto 2016).

The educators and educational staff at KAF are mostly LIPIA alumni. LIPIA is Islamic education in Indonesia endowed by Saudi Arabia and had specialty on teaching Islamic sciences. The network of LIPIA's alumni play important role in KAF and fulfill the position of the head of the $k u t t a b$ and the other organization managements.

According to Fitriani, KAF has fulfilled all components of the education system, consisting of objectives, students, structure and schedule, curriculum and content, educators, fund, facilities and infrastructure. It also pay close attention on moral aspect reflected in students manners, such as courtesy, discipline, honesty, personal and environmental hygiene, social interaction and mutual respect (Fitriani 2016).

\section{Educational Ideology of Kuttab}

Kuttab al-Fatih (KAF) Purwokerto is branch of KAF Depok. The KAF management model is centralistic, meaning all branches have the same characteristics in terms of curriculum substance. The management structure consists of several 
KAF management teams: general manager, curriculum manager, head of central Kuttab AlFatih, media manager, financial manager, kuttab manager educational media, Lentera Sirah, and subordinate manager (www.kuttabalfatih.com). Therefore, the study of KAF Purwokerto will also provide brief picture for other KAF in Indonesia.

According to Fitriani, KAF has fulfilled all components of the educational system. It has provided students with physical facility, management system, learning system and the health environment for students. It pays close attention on moral aspect reflected in students manners, such as courtesy, discipline, honesty, personal and environmental hygiene, social interaction and mutual respect (Fitriani 2016). The latter is underpinned by the ideology that KAF embrace.

The ideology that influences KAF can be traced from its founding persons, among them is Ustadz Budi Ashari, who is also active in Parenting Nabawiyah. The educational practices in KAF are much influenced by the thoughts of its founders especially Ustadz Budi Ashari (Hidayat 2018). He is initiator and founder of KAF. Ust Budi Ashari regularly appears on National TV (Trans 7) on the "Khalifah" program. The ideological root of $\mathrm{KAF}$ is to establish a generation of minhajin nubuwwah caliphs with a glorious vision at young age. The "Khalifah" TV program held by Ust Budi Ashari tells the story of Islamic history using attractive illustrations.

According to Ashari, kuttab first appeared in the time of the Prophet Muhammad PBUH and then spread along with the spread of Islam. Kuttab was the main place to teach children in the classical Islamic world. Its existence played important roles in Islamic community for it provide children with Quranic learning which becomes the core of Islamic education (Ashari 2012: 13). Such perspective is taken as the way of thinking of kuttab initiators in Indonesia, especially in Riau. In Purwokerto, KAF takes Muhammad al-Fatih, the Great Rulers of Ottoman, as role model. KAF
Purwokerto intends to educate students in order to create generation like Muhammad Al-Fatih, the conqueror of Constantinople.

The founders of Kuttab Al-Fatih laid down worldview that are central to KAF spirit of education. The KAF educational worldview is to create the caliphate generation based on prophetic mission and to create the opening generation of Rome (Ashari 2012: 22). Ashari cited prophetic traditions that contain prophecy in which Islamic society will evolve politically according to following phases: the nubuwah phase, the caliphate phase in accordance to the manhaj nubuwwah (prophetic ways), the biting government phase, the dictatorial movement phase, and the caliphate phase in accordance to the manhaj nubuwwah. This understanding is very well-known among those who idealize caliphate as best political system and civilization of Islamic society.

It is not striking that some researchers conclude KAF's thinking is kind of fundamentalism (Mustaqim 2015), someassociate it to radical Islamic movement (Mustofa, Enizar, Hadi, and Irwansyah 2019), and another includes it into conservativefundamentalist-religious ideology group (Hidayat 2018). Fundamentalism in Islam, however, has various manifestations from the reinforcing religious consciousness through rituals to the establishment of Islamic political system, especially transnational caliphate political system. Azra suggested that Islamic fundamentalism should be seen in its rich spectrum instead of simplifying it as solely having political mission. He classifies the orientation of Islamic fundamentalism into inward oriented and outward oriented movement. He former focuses on building spirituality and the awareness of Muslim to do their religious duty, while the latter push more social, as well as political, movement to embody Islam into real life of society (Azra 1996: 106-108). The conclusion that KAF contains fundamentalistic view should not automatically lead to conclusion that KAF is politically motivated institution. There is lack of evidence that KAF is set up for the sake of political purpose. 
It can be said that every educational institution has an ideological motive. Primary and secondary educational institutions under Muhammadiyah instill the values of Muhammadiyah. Likewise, schools under Maarif NU certainly instill the values of Aswaja, so do Taman Siswa and other schools owned by religious organizations. The presence of KAF Depok can be said to enliven the development and understanding of Islam in Indonesia (Utomo 2018: 146). In Muhaimin's point of view, the kuttab paradigm embraces formalism, where the development of Islamic education is more oriented to the afterlife. Students are directed to be loyal and to have a high commitment their religion. Rationalistic, analytic and critical reason is not preferred when it relate to religious belief. The reason needs to be suppressed by normative and doctrinal religious approaches instead (Muhaimin, Sutiah 2012).

The educational curriculum of Kuttab AlFatih is different from that of Islamic Education institutions in general. KAF only provide the subjects of al-Iman and Quran. There are only two teachers in Kuttab Al-Fatih, the faith and Quran teachers. The education level at Kuttab Al-Fatih is divided into two: kuttab awwal and kuttab qonuni. Kuttab awwal consists of three levels, which are class 1 , class 2 and class 3 . They are between 5 to 7 years old. Kuttab qonuni consists of four levels, which are class 1, class 2, class 3, and class 4 . They are between 8 to 12 years old. Kuttab awwal prepares the foundation of faith and Quran respectively. The material in KAF consists of two modules which are natural and human modules. The modules used in the early grades 1 and 2 are natural modules. Meanwhile grade 3, and qonuni classes 1, 2, 3, and 4 study human modules.

The natural module contains learning resources in applying character-based education through tadabbur of juz 30 of the Quran. Juz 30 is chosen because it is based on the priority sequence of the Makkiyah-Madaniyah learning phase. In addition, in general it is often used for prayer reading. Hopefully, the memorized verses can be embodied, studied, and understood so that their faith will increase and become stronger. Kuttab
Al-Fatih is is financially independent without the government's aid. KAF Purwokerto is not willing to accept assistance from the Banyumas Regency Education Office. Although registered as PKBM of the Banyumas Regency Education Office, KAF Purwokerto did not willing to accept operational and BOS assistance for kuttab. Finance system at KAF Purwokerto uses the standard of dinar and dirham money, although the payment still uses Indonesian rupiah. For example, the amount of entrance fee in KAF Purwokerto is 2 dinars (around Rp 5 million), and the amount of monthly tuition fees is 5 dirhams (about Rp 300 thousand). The current conversion rate of dinar or dirham to rupiah can be observed at www. geraidinar.com.

Every educational unit basically has two roles namely educational role which is transfer of knowledge and value inheritance which is transfer of value. KAF is an educational institution founded on the basis of Islamic faith. The dogmatic learning approach used throughout the learning activities. Studying the knowledge form the text book is not considered as the primary goal. Instilling the values of Islamic faith is more important. The ideal of KAF is to establish a generation like Muhammad Al-Fatih who was able to break through the fortress of Constantinople. The goal of faith nurturing within $\mathrm{KAF}$ is to create a generation of caliphate. Kuttab is an instrument for creating the next generation by copying educational practices proven to create a great generation of the golden age of Islam with a glorious vision at a young age.

KAF Purwokerto's ideology is conservativefundamentalist-religious (Hidayat 2018). It is conservative because it wants to revive something that has existed in a fundamental way (directly). One that has always existed is the concept of Islamic state (theocracy). The view of "integration of religions" and on the contrary "separation of religions" does not conform to Pancasila. The founding fathers of the nation, after much reflection, chose Pancasila as national and state values. Therefore, religious education is not intended to "instill value" in the establishment 
of a state based on religion (theocracy) but to strengthen the state of Pancasila. The view of the caliphate above manhaj nubuwwah is irrelevant to the present view. Indonesia is more properly called a religious country although it is not. A country gives religion a large space and attention. Religion is the spirit and inspiration for the advancement of the nation. Indonesia is a country that ensures that every citizen is free to embrace religion and worship according to his/ her beliefs. The paradigm of formism, in which the development of Islamic education is more directed towards being a loyal performer, has a high commitment and dedication to the religion. However, learning empirical and rational things should be used, not merely in a normative and doctrinal approach.

\section{KAF's Concept of Islamic Education}

There are learning characteristics within the Kuttab Al-Fatih: (1) manners before knowledge, (2) knowledge before charity, and (3) faith before the Quran (Hafnidar, Mansor, and Nichiappan 2020). Therefore, the focus of Kuttab learning is more about manners or morals. In addition, Kuttab revives the "romanticism" of the past glory of Islam in various aspects. The name Kuttab itself was chosen because it is indeed the original "inheritance" of the prophet. An Islamic hospital does not mean that the hospital is Islamic. An Islamic school does not mean that the school is Islamic either. The name "kuttab" was chosen because it is naturally Islamic. The level of education in Islam itself only recognizes two levels: basic education (kuttab) and upper education (madrasa). In Islam there is no middle level knowledge. Learning developed tends to a model "ancient" by way of lesehan (sitting without chairs). In practice faith learning is studying the Quran thematically. There are three modules in KAF which are natural modules, human modules, and tadabbur Quran.

A nature module specially is about investing faith through natural approaches in juz 30 . Here, there are sevenmajor themes relating to nature that are mentioned from An-Naba surah (beginning of juz) to An-Nas surah. The seven major themes are time, element, energy, earth surface, living creature, season, and solar system. While the human module consists of physics theme, spirits, characters, and interactions (Modul Manusia 2019: 6-9).

The Islamic educational institution of Kuttab $\mathrm{Al}-$ Fatih is a level of education with an elementary school that is different from the educational institutions that have developed in Indonesia. Kuttab Al-Fatih does not use a government curriculum but instead draws up its own curriculum with reference to the classical Islamic education model. The aim of the establishment of this educational institution is to provide basic education referring to the Islamic education of the classical period which has ushered in the glory of Islam in its time by originating in Quran and Hadith. Kuttab al-Fatih tries to restore Islamic education in accordance with education developed by Muslims in the classical period, namely the time of the Prophet, Khulafa al-Rashidin, Banu Umayyah, and Banu Abbasiyah (Ramadhani 2018: 7). One tangible manifestation of ideology in educational institutions is in the presented kuttab curriculum.

The curriculum taught is very important, so it needs to be bequeathed to the next generation (students). Faith and the Quran are the very important things. Therefore, learning in KAFincludes two things: al-Iman and Quran. The teachers at KAF consist of two teachers that are the faith and al-Quran teachers. Parents are involved largely in learning at KAF. Learning at KAF does not merely function as an education/learning tool for children but also forms a community. In KAF, parents of guardians of students are also required take a part to study in the form of Parents' Schools. Understanding the management of children's educational success is influenced by $60 \%$ of education in the family. Learning also involves parents where children are assigned to study with parents. All KAF learning activities are in the context of increasing faith in Allah SWT. The function of "inheritance of value" in KAF is greater than the function of "education". 
The value inheritance function in KAF appears in the curriculum composition that only contains two subjects; al-Iman and Quran. The emphasis of education on kuttab is about manners, morals or daily behavior of students. Kuttab education is more concerned with teachers than school infrastructure. The teacher at KAF is called Ustadz. Likewise, students are called santri. The educational level at KAF is divided into two: kuttab awwal and kuttab qonuni. Kuttab awwal consists of three levels (1-2-3). The students in these levels is at age 5 to 7 years. Meantime, kuttab qonuni consists of four levels (1-2-3-4). The child in these levels is 8 to 12 years old. Substantially the curriculum applied to KAF is $100 \%$ related to religion (Islam). KAF financing is independent and does not rely on government assistance. KAF does not receive school operational assistance and any assistance from the government.

The implication of the concept of KAF Education model can change and/or complement the subject matter of Islamic education so far. Institutionally the concept of Islamic education has been developed through Islamic boarding schools/pesantren, madrasas, and Islamic schools. However, now kuttab has its own characteristics and is claimed to be an "original Islamic" educational institution at the elementary level (TK/RA/ SD/MI). From the subjects, so far the study of religion at the elementary level is known as Islamic Religious Education. In madrasa, Islamic learning is divided into four subjects: Quran Hadith, Fiqh, Islamic cultural History, and Faith and Morals. Religious learning in kuttab only recognizes "faith" and "Quran". Learning in kuttab is focused only on studying Quran. Textual Quran becomes the object as well as a source of major values in attitudes and behavior. Factually learning Quran is memorizing (tahfidzul quran). The main focus is on juz 30. In KAF "al-Iman" becomes the main learning besides "Quran". Even faith must take precedence before Quran.

Besides the implications related to Islamic Education institutions and the composition of Islamic Religious Education ( $P A I$ ) curriculum material, kuttab also has the potential to create tension related to religious and state relations. The aim of the KAF curriculum which creates a generation of ala minhajin nubuwwah, has in common with the concept of a theocracy state or a model of religious-state integration. This model is not in line with the concept of Pancasila state in which religion is a state spirit. The belief about khilafah ala minhajin nubuwwah has the potential to face between religion and state. In the view of Nahdlatul Ulama scholars, the concept of the Unitary Republic of Indonesia is fixed. Meanwhile, the concept of Pancasila State is Dar al-Ahli wa al-Syahadah (state in agreement) according to the results of the Muhammadiyah Congress. The concept of Dar al-Ahli wa Al-Syahadah stresses "Indonesia is neither a state labeled Islam (dar al-Islam) nor secular a secular infidel that should be fought (dar al-harb). Indonesia is a state that ideally implements Islamic values, nurtures all groups and promotes civilized deliberative democracy, which is actually strongly encouraged by Islamic teachings (Muhammadiyah 2019).

\section{CONCLUSION}

The ideological roots of the founder of KAF are, in fact, reviving the concept of Islamic civilization with political aspect as the core. The thought of the founder of KAF is dominated by the vision to create a generation of khilafah under the prophetic method (manhaj). Kuttab is an instrument for creating superior generations by reviving educational practices ofthe past that have been proven to be successful to bring Islamic society into the Golden Age of Islamic civilization. The ideological characteristics of KAF are religiously conservative and fundamentalistic. The applied education pattern seeks to maintain the educational traditions of the times of the prophet, friends, and tabiin, the Golden Era of Islam. The foundation of his thought is fundamentalist-religious, that is, the foundation of thought sourced from the main sources of Quran, hadith and siroh. The spirit of education 
returns the ancient educational pattern, the spirit of restoration of Islamic education. The founder of KAF adheres to the formism paradigm in which the development of Islamic education is more oriented to the afterlife. Students are directed to be loyal, have a high commitment to the religion. The learning approach used is normative and doctrinaire.

The kuttab education model has implications for the concept of education in Islam. In terms of the practice of Islamic education so far, educational institutions consist of pesantren, madrasas and Islamic schools. Nowadays, kuttab enriches educational institutions although it is not formally recognized by the state. So far, Islamic Education material has been patterned into two models. Firstly, the subject is applied to public schools i.e. PAI. Secondly, the material in madrasas is divided into four subjects: (1) Quran Hadith, (2) Fiqh, (3) Islamic Cultural History, and (4) Faith and Morals. Besides, it is added with Arabic Education subjects. In the kuttab model, Islamic Education material is divided into only two subjects, namely: Qurani and Imani. Likewise, the teachers are only categorized into two, Quran and Al-Iman teachers. Another implication is the kuttab's view regarding the relations of religion and the state. The aim of the $\mathrm{KAF}$ curriculum which creates a generation of ala minhajin nubuwwah, has in common with the concept of a theocracy state or a model of religious-state integration. This model is not in line with the concept of the Pancasila state in which religion is a state spirit.

\section{REFERENCES}

Al-Attas, S. M. N. 1980. The Concept of Islamic Education. The Keynote Address Delivered at the First World Conference on Muslim Education. https://doi. org/10.1007/s13398-014-0173-7.2.

Ashari, B. and I. S. 2012. Modul Kuttab Satu; AlFatih Pilar Peradaban. Depok: Yayasan Al-Fatih.

Asy'ari, H. 2011. Relasi Negara dan Agama di
Indonesia. Jurnal Rechtsvinding. https:// doi.org/10.1016/j.msec.2013.12.034.

Azra, A. 1996. Pergolakan Politik Islam; dari Fundamentalisme, Modernisme, hingga Post Modernisme. Jakarta: Paramadina.

Baidarus, Tasman Hamami, Fitriah M.Suud,A.S.R. 2019. Al-Islam dan Kemuhammadiyahan sebagai Basis Pendidikan Karakter. AlAsasiyya: Journal Basic of Education, 4(1): 71-91.

Baiza, Y. 2018. Islamic Education and Development of Educational Traditions and Institutions. Handbook of Islamic Education: 7797. https://doi.org/10.1007/978-3-31964683-1_7.

Batubara, H. H., and Ariani, D. N. 2016. Kuttab sebagai Potret Pendidikan Dasar Periode Klasik. Muallimuna: Jurnal Madrasah Ibtidaiyah: 1(2): 98-111 https://doi. org/10.31602/muallimuna.v1i2.388.

Bisri, F. dan C. H. 2002. Dinamika Pemikiran Islam di Perguruan Tinggi; Wacana tentang Pendidikan Agama Islam. Jakarta: Logos Wacana Ilmu.

Boyle, H. N., and Boukamhi, A. 2018. Islamic Education in Morocco. International Handbooks of Religion and Education Vol. 7 https://doi.org/10.1007/978-3319-64683-1_37.

Fahmi, M. 2016. Pendidikan Aswaja NU dalam Konteks Pluralisme. Jurnal Pendidikan Agama Islam (Journal of Islamic Education Studies): 1(1): 161-179. https://doi.org/10.15642/ pai.2013.1.1.161-179.

Fitriani, E. 2016. Implementasi Pendidikan Akhlak di Kuttab Al-Fatih Semarang. Fakultas Ilmu Pendidikan UNNES, Skripsi.

Fuaduddin, C. H. B. (Ed.). 2002. Dinamika Pemikiran Islam di Perguruan Tinggi; Wacana tentang Pendidikan Agama Islam. Jakarta: Logos Wacana Ilmu.

Gulliot, C. 2012. Education and Learning in The Early Islamic World. Farnham and Burlington: Ashgate Publishing.

Hafnidar, H., Mansor, R., and Nichiappan, S. 2020. The Implementation of Role 
of Kuttab Al-Fatih (KAF) Philosophy in Islamic Character Education. Nadwa, 13(2): 235-250. https://doi. org/10.21580/nw.2019.13.2.5184.

Haningsih, S. 2008. Peran Strategis Pesantren, Madrasah dan Sekolah Islam di Indonesia. El-Tarbawi, 1(1): 27-39. https://doi. org/10.20885/tarbawi.vol1.iss1.art3.

Hidayat, F. 2018. Pertumbuhan Ideologi Pendidikan di Era Reformasi (Kajian Terhadap Ideologi Pendidikan di Kuttab Al Fatih Purwokerto). Literasi (Jurnal Ilmu Pendidikan), 8(2): 85-98. https://doi. org/10.21927/literasi.2017.8(2).85-98.

Makdisi, G. 1981. The Rise of Colledge: Institutions of Learning in Islam and the West. Edinburgh: Edinburgh University Press.

Modul Manusia. 2019.

Muhaimin, Sutiah, N. A. 2012. Paradigma PendidikanIslam; UpayaMengefektifkan Pendidikan Agama Islam di Sekolah (Cet ke-5). Bandung: PT Remaja Rosdakarya.

Muhammadiyah, S. 2019. Majalah Suara Muhammadiyah.Suara Muhammadiyah, Edisi Nomor 14, 16-31 Juli 2019.

Muspiroh, N. 2019. Kuttab sebagai Pendidikan Dasar Islam dan Peletak Dasar Literasi. Jurnal Tamaddun: Jurnal Sejarah dan Kebudayaan Islam, 7(1): 169-192. https://doi.org/10.24235/tamaddun. v7i1.4506.

Mustaqim, M. 2015. Tantangan Negara-Bangsa (Nation-State) dalam Menghadapi Fundamentalisme Islam. Addin, 9(1): 85-106. https://doi.org/http://dx.doi. org/10.21043/addin.v9i1.608.

Mustofa, I., Enizar, Hadi, M., and Irwansyah, D. 2019. Reading Types of Islamic Fundamentalism in Lampung Province: (A Study on Doctrine and Movement of Islamism at Lampung University). Qudus International Journal of Islamic Studies, 7(2): 267-30o.https://doi.org/10.21043/ qijis.v7i2.5719.

Nelliraharti, and Sari, Y. 2019. Pelaksanaan Program Parenting Bagi Orang tua Siswa di Kuttab Al Fatih Banda Aceh. Journal of

\section{Education Science (JES).}

Pratama, M. R. 2016. Manajemen Pendidikan di Kuttab Al-Fatih Semarang. Fak Ilmu Pendidikan UNNES, Skripsi.

Putranto, S. D. 2016. Sistem Pendidikan Islam Model Kutttab (Studi Kasus di Kuttab AlFatih Malang). Fakultas Ilmu Tarbiyah dan Keguruan UIN Maliki Malang, Skripsi.

Rahman, F., Pembaharuan, D., Tafsir, M., Metodologi, D. P., and Alquran, T. 2013. Fazlur Rahman dan Pembaharuan Metodologi Tafsir Alquran. Media Akademika.

Ramadhani, M.Y. R. 2018.Mungkinkah Kurikulum Kuttab Menjadi Kurikulum Nasional. Makalah Akademi Guru Al-Fatih 4.

Riyadi, Arie Rakhmat. 2019. Pedagogic Fundamental Structure of Kuttab Al-Fatih as a Model of Islamic Prophetic Based Elementary Education. Proceeding of the $5^{\text {th }}$ International Conference on Education and Technology. https://doi.org/10.2991/ icet-19.2019.127.

Sandi, Galan Nurrahman. 2021. Menemukan Akar Pendidikan Kuttab di Nusantara. Opini, 26/1/2021. https://www.kuttabalfatih. $\mathrm{com} / \mathrm{menemukan-akar-pendidikan-}$ kuttab-di-nusantara/.

Saputri, A. D. 2017. Reaktualisasi Kuttab dalam Pendidikan Islam di Sekolah Tahfidz Tingkat Dasar Tabarok Surakarta. Fak Ilmu Tarbiyah dan Keguruan IAIN Surakarta, Skripsi.

Saugi, W. 2020. Implementation of Curriculum Kuttab Al-Fatih on Children at an Early Age. Jurnal Obsesi: Jurnal Pendidikan Anak Usia Dini, 5(1): 70-84. https:// doi.org/10.31004/obsesi.v5i1.510.

Sofanudin, A. 2012.Studi Tahapan Penanganan Kasus Jemaat Ahmadiyah Indonesia (JAI). 11(2): 15-24. Retrieved from https://jurnalharmoni.kemenag.go.id/ index.php/harmoni/article/view/240

Sofanudin, A. 2019a. Best Practice Implementasi Kurikulum pada Sekolah Alam Insan Mulia (SAIM) Surabaya. Jurnal Smart (Studi Masyarakat, Religi, dan Tradisi), 5(1): 15-27. https://doi.org/10.18784/ 
smart.v5i1.744.

Sofanudin, A. 2019b. Curriculum Typology of Islamic Religion Education in Integrated Islamic School (SIT). Edukasi: Jurnal Penelitian Pendidikan Agama dan Keagamaan, 17(1): 42-56. https://doi. org/10.32729/edukasi.v17i1.563.

Sofanudin, A. dkk. 2019c. Kuttab Diawasi atau Diadopsi. Retrieved March 12, 2020, from Policy Brief Balai Penelitian dan Pengembangan Agama Semarang website: https://blasemarang.kemenag. go.id/2019/12/31/policy-briefpenelitian-implementasi-pendidikanagama-pada-kuttab-di-jawa-tengah/.

Sofanudin, A. 2021. Kuttab itu Pesantren? Tribun Jateng. Retrieved from https://jateng. tribunnews.com/2021/05/o5/opinikuttab-itu-pesantren\#: :text=Kuttab ad alahpesantrentanpaasrama,Islamiyah (KMI) pada Gontor.

Sofanudin, A. 2021. Bersama Merawat Indonesia. TribunJateng. Retrieved from https:// jateng.tribunnews.com/2021/07/02/ opini-dr-aji-sofanudin-bersamamerawat-indonesia.

Sofanudin, A. dkk. 2021. Model Pengelolaan Pendidikan Agama pada Kuttab.
Semarang: Balai Penelitian dan Pengembangan Agama Semarang.

Steenbrink, K. A. 1986. Pesantren Madrasah Sekolah; Pendidikan Islam dalam Kurun Moderen (Pertama). Jakarta: Lembaga Penelitian, Pendidikan dan Penerangan Ekonomi dan Sosial.

Tafsir, A. 2004. Cakrawala Pemikiran Pendidikan Islam. Bandung: Mimbar Pustaka, cetakan pertama.

Ulwiyah, N., Maftuhatin, L., \& Samsukadi, M. 2019. Implementation of Islamic Character Education With Intervention Approach and Micro Habituation of Education in Kuttab Al-Fatih Jombang. Didaktika Religia, 6(2): 245-272. https:// doi.org/10.30762/didaktika.v6i2.1106.

Utomo, A. 2018. Kurikulum Pendidikan Agama Islam di Madrasah Berbasis Kuttab (Studi Kasus di Kuttab Al-Fatih Depok). Tesis Prodi Pendidikan Islam, Program Pascasarjana UIN Sunan Kalijaga Yogyakarta.

Yumitro, G. 2018. Peluang dan Tantangan Gerakan Revivalisme Islam di Indonesia Pasca Reformasi. Tsaqafah, 14(1): 5572. https://doi.org/10.21111/tsaqafah. v14i1.2296. 